\title{
Keefektifan Model Teams Games Tournament Terhadap Minat Belajar
}

\author{
Angilia Herli Lutfiyani* \\ Pendidikan Guru Sekolah Dasar, Fakultas IImu Pendidikan, Universitas PGRI Semarang
}

\section{A R T I C L E I N F O}

Article history:

Received 10 February 2019

Received in revised form 09 March 2019

Accepted 15 April 2019 Available online 25 May 2019

\section{Kata Kunci:}

Minat Belajar Siswa, Model

Teams Games Tournamnet

Keywords:

Interest in Student Learning, Teams Games Tournament Model

\begin{abstract}
A B S T R A K
Penelitian ini bertujuan untuk mengetahui keefektifan model pembelajaran Teams Games Tournament terhadap minat belajar siswa kelas V SDN 01 Ngeling Kabupaten Jepara. Jenis penelitian ini merupakan penelitian kuantitatif dengan desain Pra Experimental Design dalam bentuk One-Group Pretest Posttest Design. Data dalam penelitian diperoleh melalui (1) observasi, (2) lembar angket, dan (3) dokumentasi. Untuk analisis data dalam penelitian ini menggunakan uji normalitas dan uji t (uji hipotesis). Hasil analisis lembar angket minat belajar siswa sebelum dan sesudah perlakuan menggunakan model pembelajaran Teams Games Tournament mengalami peningkatan, terlihat dari hasil uji $t$ bahwa thitung $>$ tabel yaitu $9,305>2,110$. Maka kesimpulannya adalah model Teams Games Tournament efektif terhadap minat belajar siswa.
\end{abstract}

\begin{abstract}
A B S T R A C T
This study aims to determine the effectiveness of the Teams Games Tournament learning model on the interest in learning in fifth grade students of SDN 01 Ngeling, Jepara Regency. This type of research is a quantitative study with the design of Pre Experimental Design in the form of One-Group Pretest Posttest Design. Data in the study were obtained through (1) observation, (2) questionnaire sheets, and (3) documentation. For data analysis in this study using the normality test and $t$ test (hypothesis test). The results of the analysis of student learning interest questionnaire sheets before and after treatment using the Teams Games Tournament learning model have increased, as seen from the results of the $t$ test that $t$ count $>t$ table is 9,305> 2,110. So the conclusion is the Teams Games Tournament model is effective against students' learning interests
\end{abstract}

\section{Pendahuluan}

Pendidikan merupakan sebuah sarana penting untuk pertumbuhan dan kelangsungan hidup bagi seseorang atau suatu bangsa. Pendidikan adalah kegiatan nyata yang disengaja untuk dilakukan supaya siswa memiliki kepribadian yang baik. Menurut Undang-undang Nomor 20 tahun 2003 tentang Sistem Pendidikan Nasional menyatakan bahwa. "Pendidikan sebagai usaha sadar dan terencana untuk mewujudkan suasana belajar dan proses pembelajaran agar peserta didik secara aktif mengembangkan potensi dirinya, untuk memiliki kekuatan spiritual keagamaan, pengendalian diri, kepribadian, kecerdasan, akhlak mulia, serta keterampilan yang diperlukan dirinya, masyarakat, bangsa, dan negara". Pendidikan dalam lingkungan sekolah lebih bersifat formal, guru sebagai pendidik di sekolah disiapkan secara formal dalam lembaga pendidikan keguruan sehingga memiliki kepribadian sebagai pendidik. Guru merupakan salah satu faktor pendidikan yang memiliki peran yang paling strategis, karena guru merupakan faktor paling menentukan pada saat terjadinya proses belajar mengajar. Berkaitan dengan hal tersebut, Haidar (dalam Susanna, 2017) menyatakan bahwa, "Di bidang keguruan ada tiga persyaratan pokok seseorang itu menjadi tenaga professional dibidang keguruan. Pertama, memiliki ilmu pengetahuan

Copyright (c) Universitas Pendidikan Ganesha. All rights reserved. 
dibidang yang diajarkan sesuai dengan kualifikasi dimana ia mengajar. Kedua, memiliki pengetahuan dan keterampilaan dibidang keguruan. Ketiga, memiliki moral akademik".

Untuk mencapai tujuan tersebut maka diselenggarakan serangkaian kegiatan pembelajaran yang bersifat formal, non formal, maupun informal dengan berbagai jenjang mulai dari pendidikan usia dini hingga pendidikan tinggi. Salah satunya adalah pendidikan di Sekolah Dasar. Pendidikan pada usia Sekolah Dasar adalah fondasi untuk membentukan minat belajar siswa. Dalam proses pendidikan inilah perlu ditekankan bahwa bagaimana agar peserta didik mau belajar, bukan hanya sekedar bagaimana guru mengajar. Dalam proses pembelajaran di kelas dipengaruhi oleh faktor eksternal dan faktor internal. Faktor eksternal merupakan faktor yang berasal dari luar diri siswa, sedangkan faktor internal adalah faktor yang berasal dari dalam diri siswa. Faktor eksternal dan faktor internal inilah yang mempunyai peranan penting dalam keberhasilan proses pembelajaran selama di kelas. Salah satu faktor internal yang mempengaruhi proses pembelajaran adalah Motivasi Belajar. Motivasi Belajar merupakan dorongan yang terdapat dalam diri siswa untuk berusaha mengadakan perubahan perilaku untuk mencapai tujuan yang ingin dicapai. Motivasi dapat membantu dalam memahami dan menjelaskan perilaku individu, termasuk perilaku saat sedang belajar. Proses pembelajaran dapat dikatakan berhasil apabila siswa memiliki Motivasi Belajar yang tinggi. Apabila Motivasi Belajar rendah, maka perlu diterapkan adanya model pembelajaran yang menarik, menyenangkan, serta mampu memberi rangsangan kepada siswa agar semangat dan penuh gairah dalam belajar.

Menurut Daryanto (2010) Belajar ialah suatu proses usaha yang dilakukan seseorang untuk memperoleh suatu perubahan tingkah laku yang baru secara keseluruhan, sebagai hasil pengalamannya sendiri dalam interaksi dengan lingkungannya. Susanto (2010) menyatakan minat merupakan dorongan dalam diri seseorang atau faktor yang menimbulkan ketertarikan atau perhatian secara efektif, yang menyebabkan dipilihnya suatu objek atau kegiatan yang menguntungkan, menyenangkan, dan lamakelamaan akan mendatangkan kepuasan dalam dirinya. Menurut Syah (dalam Riwahyudin, 2015) bahwa minat adalah kecenderungan dan kegairahan yang tinggi atau keinginan yang besar terhadap sesuatu.

(Sardiman, 2012: 76), mengartikan bahwa minat merupakan sebagai sutau kondisi yang terjadi apabila seseorang melihat ciri-ciri atau arti sementara situasi yang dihubungkan dengan keinginankeinginan atau kebutuhan-kebutuhannya sendiri. Maka dari itu, apa saja yang dilihat seeseorang sudah tentu akan membangkitkan minatnya sejauh apa yang dilihatnya mempunyai hubungan dengan kepentingannya sendiri. Hal ini menunjukkan bahwa minat merupakan kecenderungan jiwa seseorang terhadap suatu objek (biasanya disertai dengan perasaan senang), karena itu merasa ada kepentingan dengan sesuatu itu.

Menurut Olivia (Nurhasanah \& Soebandi, 2016: 137), minat belajar adalah sikap ketaatan pada kegiatan belajar, baik menyangkut perencanaan jadwal belajar maupun inisiatif melakukan usaha tersebut dengan sungguh-sungguh. Adapun peranan penting minat belajar menurut (Susanto, 2010: 68), minat belajar anak merupakan salah satu faktor yang sangat penting dalam menunjang tercapainya efektifitas proses belajar mengajar, yang pada akhirnya akan berpengaruh terhadap hasil belajar anak yang bersangkutan. Siswa yang memiliki minat belajar yang tinggi dapat menunjang proses pembelajaran menjadi lebih baik dan sebaliknya apabila minat belajar semakin rendah, maka akan berdampak buruk buat proses dan hasil pembelajaran. Oleh karena itu, minat belajar siswa itu penting untuk ditingkatkan.

Mengingat pentingnya minat belajar dalam proses pembelajaran, namun kenyataannya minat belajar siswa masih rendah. Siswa kurang berminat dalam belajar dengan bersungguh-sungguh. Siswa masih merasa bosan dalam mengikuti proses pembelajaran di kelas karena pembelajaran terasa monoton. Hal tersebut menyebabkan beberapa siswa tidak bersemangat ataupun berminat serta tidak aktif dalam mengikuti pembelajaran di kelas. Karena siswa tidak bersemagat dalam mengikuti pembelajaran menyebabkan siswa tidak memahami sepenuhnya tentang materi yang disampaikan oleh guru. Kemampuan yang harus dimiliki seorang guru salah satunya adalah pemilihan dan penggunaan model pembelajaran yang tepat dan mampu merangsang minat siswa agar aktif dalam proses belajar mengajar.

Berdasarkan hasil pengamatan yang dilakukan pada SDN 01 Ngeling Kabupaten Jepara terdapat masalah yang timbul berkaitan dengan pembelajaran pada kelas $\mathrm{V}$ yaitu kurangnya minat dalam mengikuti pembelajaran atau kurang dalam memperhatikan belajar. Terlihat bahwa saat di dalam kelas siswa masih suka bermain sendiri, bahkan ada yang suka berbicara sendiri dengan temannya dan tidak memperhatikan penjelasan guru, ketika guru memberikan pertanyaan siswa tidak menanggapinya, bahkan saat siswa ditunjuk tidak dapat menjawab. Minat belajar yang rendah karena adanya rasa bosan dalam mengikuti proses pembelajaran karena metode maupun model pembelajaran yang digunakan masih bersifat konvensional (monoton) dan kurang bervariasi. Sehingga anak menjadi bosan, pasif serta tidak fokus untuk mengikuti proses pembelajaran yang berlangsung. Ketika siswa merasa bosan dalam mengikuti pembelajaran maka akan timbul rasa malas untuk belajar. Akibatnya siswa tidak memahami sepenuhnya materi yang disampaikan oleh guru. Model pembelajarn yang bervariasi juga sangat penting 
diterapkan untuk proses pembelajaran. Selain pemilihan model pembelajaran yang inovatif, cara mengajar yang menyenangkan perlu didukung dengan adanya media pembelajaran yang menarik perhatian siswa, sehingga siswa bersungguh-sungguh dalam mengikuti pembelajaran matematika dan dapat meningkatkan hasil belajar. Salah satu pembelajaran yang menyenangkan adalah belajar sambil bermain. Bermain menurut Brewer dalam (Pratiwi, 2012: 110) adalah kegembiraan, sebuah kegiatan yang menyenangkan ketika melakukannya, bebas dari paksaan atau tekanan luar, spontan dilakukan dengan sukarela.

Setiap siswa merupakan makhluk hidup yang memiliki prinsip aktif. Mc Keachie dalam (Dimyati \& Mudjiono, 2009: 45) menjelaskan bahwa "individu merupakan manusia belajar yang aktif selalu ingin tahu". Sehingga setiap siswa akan melakukan kegiatan/aktivitas untuk mempelajari segala sesuatu yang ingin diketahuinya. Keaktifan menjadi faktor yang penting dalam pembelajaran, sehingga hendaknya guru tidak hanya menekankan aspek kognitif yang meliputi pemahaman bahan pengetahuan, melainkan juga harus berperan sebagai fasilitator yang mengarahkan, membimbing, dan memfasilitasi kegiatan belajar siswa. Keaktifan siswa dapat ditingkatkan melalui pemilihan model pembelajaran yang mampu memberikan kesempatan kepada seluruh siswa untuk terlibat aktif pada saat pembelajaran berlangsung.

Berdasarkan masalah di atas, maka untuk mengatasi permasalahan yang ada dibutuhkan suatu model pembelajaran baru yang akan diterapkan dalam proses pembelajaran yang dapat menumbuhkan minat belajar siswa, sehingga membuat siswa mampu mengikuti pembelajaran dengan senang hati tanpa adanya unsur keterpaksaan. Model pembelajaran yang diduga dapat memecahkan permasalahan tersebut adalah salah satu tipe pada model pembelajaran kooperatif. Pembelajaran kooperatif merupakan salah satu model pembelajaran yang memberikan kesempatan kepada siswa untuk melakukan interaksi dan berpartisipasi aktif selama pembelajaran berlangsung. Menurut Trianto (2014) "pembelajaran kooperatif disusun dalam sebuah usaha untuk meningkatkan partisipasi siswa, memfasilitasi siswa untuk belajar bersama-sama siswa yang berbeda latar belakangnya." Dengan model ini siswa dilatih untuk mengembangkan kemampuan berpikir logis, analitis, sistematis, kreatif, dan kritis, serta kemampuan untuk bekerjasama. Menurut Slavin Dalam (Taniredja, Tukiran \& Faridli, Efi Miftah \& Harmianto, 2011) "Pembelajaran Kooperatif adalah pembelajaran yang dilakukan secara berkelompok, siswa dalam satu kelas di jadikan kelompok-kelompok kecil dengan memperhatikan kaberagaman anggota kelompok sebagai wadah siswa bekerja sama dan memecahkan suatu masalah melalui interaksi sosial dengan teman sebayanya, memberikan kesempatan pada peserta didik dan ia menjadi narasumber bagi teman yang lain. Jadi pembelajaran kooperatif merupakan model pembelajaran yang mengutamakan kerja sama diantara siswa untuk mencapai tujuan pembelajaran". Salah satu tipe dari pembelajaran kooperatif yaitu model pembelajaran Teams Game Tournament. Penerapan model pembelajaran ini diharapkan dapat menumbuhkan minat belajar siswa. Teams Games Tournament adalah salah satu model pembelajaran kooperatif yang menempatkan siswa dalam kelompok-kelompok belajar yang beranggotakan 5 sampai 6 orang siswa yang memiliki kemampuan, jenis kelamin dan suku kata atau ras yang berbeda (Fathurrohman, 2017: 55).

TGT memungkinkan siswa dapat belajar lebih relaks di samping menumbuhkan tanggung jawab, kerja sama, persaingan sehat, dan keterlibatan belajar (Kariyana, 2014). (Purwandari, 2017) mengatakan bahwa "dengan menerapkan model pembelajaran TGT di kelas diharapkan dapat menghilangkan anggapan siswa tentang pelajaran yang membosankan". (Sudimahayasa, 2015) mengatakan bahwa TGT menambahkan dimensi kegembiraan yang diperoleh dari penggunaan permainan.

Menurut (Sohimin, 2014: 204-205) ada 5 komponen utama dalam Teams Games Tournament adalah penyajian kelas, kelompok (teams), Game, turnamen dan team recognize (penghargaan kelompok). Model pembelajaran Teams Games Tournament membuat peserta didik menjadi lebih senang dalam mengikuti pelajaran karena ada kegiatan permainan berupa turnamen dalam model ini (Sohimin, 2014: 207). Model Teams Games Tournament ini memiliki beberapa kelebihan, diantaranya adalah (a) siswa yang berkemampuan akademi lebih rendah juga ikut aktif dan mempunyai peranan penting dalam kelompoknya (b) menumbuhkan rasa kebersamaan dan saling menghargai sesama anggota (c) membuat peserta didik menjadi lebih bersemangat dalam mengikuti pelajaran (d) membuat peserta didik menjadi lebih senang dalam mengikuti pelajaran karena ada kegiatan permainan berupa turnamen. Selanjutny dalam pembelajaran kooperatif tipe Teams Games Tournament ini terdapat beberapa tahapan. Tahap pertama, yaitu penyajian materi. Pada tahap ini guru menyampaikan materi pelajaran dan memotivasi siswa serta menyampaikan tujuan pembelajaran kepada siswa. Tahap kedua, kegiatan kelompok. Pada tahap ini siswa mengerjakan LKS secara berkelompok. Tahap ketiga, siswa melakukan games (permainan). Pertanyaan dalam game disusun dan dirancang dari materi yang relevan dengan materi yang telah disajikan oleh guru. Tahap keempat, siswa melakukan turnamen. Pada tahap ini siswa akan bermain di dalam meja turnamen. Turnamen adalah susunan beberapa game yang dipertandingkan. Biasanya turnamen dilakukan pada akhir minggu setelah guru melakukan presentasi dan kelompok sudah 
mengerjakan lembar kerja. Tahap kelima adalah pemberian reward (penghargaan). Pada tahap ini guru memberikan penghargaan kepada kelompok-kelompok yang memenuhi kriteria tertentu (Slavin, 2009)

Dan tujuan dalam penilitian ini adalah untuk mengetahui keefektifan model Teams Games Tournament Terhadap minat belajar siswa kelas V SDN 01 Ngeling Jepara.

\section{Metode}

Penelitian ini menggunakan metode kuantitatif dengan bentuk Pra Experimental Design dengan menggunakan One-Group Pretest Posttest Design. Penelitian dilaksanakan di SDN 01 Ngeling Jepara pada tanggal 11 dan 15 Januari 2018 tahun 2018/ 2019 pada siswa kelas V. Dengan demikian hasil perlakuan dapat diketahui lebih akurat apabila dibandingkan dengan hasil sebelum diberi perlakuan. Teknik pengumpulan data dalam penelitian ini melalui observasi, lembar angket minat belajar siswa, dan dokumentasi.Dan validitas dalam peneilitian ini adalah validitas angket minat belajar siswa oleh dosen ahli. Analisis data penilitian ini mennggunakan uji normalitas untuk menganalisis data awal yaitu data sebelum diberi perlakuan dan data akhir setelah diberi perlakuan menggunakan model Teams Games Tournament dan uji t untuk menguji hipotesis keefektifan penelitian ini dengan menggunakan microsoft excel.

\section{Hasil dan Pembahasan}

Hasil penelitian ini didapatkan dua hasil, yaitu hasil pretest dan posttest. Dimana pretest merupakan hasil atau skor angket minat belajar sebelum diberi perlakuan dan posttest merupakan hasil atau skor angket minat belajar setelah diberikan perlakuan menggunakan model Teams Games Tournament. Penelitian ini bertujuan untuk mengetahui keefektifan model pembelajaran Teams Games Tournament terhadap minat belajar siswa kelas V. Penelitian ini menggunakan angket yang berjumlah 25 pernyataan dari lima indikator dari (Slameto, 2010: 180-181) untuk mendapatkan data minat belajar siswa kelas V SDN 01 Ngeling Kabupaten Jepara. Data hasil penelitian diperoleh dari hasil pretetst dan posttets penilaian angket minat belajar siswa.

Tabel 1. Data hasil pretest dan prostest

\begin{tabular}{ccc}
\hline Keterangan & Pretest & Posttest \\
\hline Nilai tertinggi & 91 & 98 \\
Nilai terendah & 63 & 76 \\
Rata-rata & 75,83 & 87,22 \\
\hline
\end{tabular}

Berdasarkan Tabel 1 dapat diketahui bahwa hasil angket minat belajar sebelum diberi perlakuan (pretest) mendapatkan rata-rata 75,83, sedangkan untuk hasil angket minat belajar siswa setelah diberi perlakuan (posttest) mendapatkan rata-rata 87,22. Dari hasil data pretest dan posttest menunjukkan bahwa rata-rata nilai posttest lebih tinggi dari hasil pretesthal tersebut terjadi karena adanya perlakuan menggunakan model Teams Games Tournament dalam proses belajar mengajar di kelas pada waktu penelitian dilakukan.

Selanjutnya akan menghitung uji hipotesis, namun sebelumnya data dianalisis terlebih dahulu dengan menggunakan uji normalitas, disini uji normalitas dilakukan untuk menguji hasil data sebelum diberi perlakuan dan setelah diberi perlakuan menggunakan model Teams Games Tournament. Uji normalitas digunakan untuk mengetahui apakah hasil data nagket sebelum dan sesudah diberi perlakuan merupakan data berdistribusi normal atau tidak. Uji normalitas yang digunakan dalam penelitian ini adalah uji Liliefors dengan taraf signifikan sebesar 0,05, dengan ketentuan bahwa jika $\mathrm{L}_{0}<$ Ltabel maka data berdistribusi normal. 
Tabel 2. Hasil Uji Normalitas Data Awal

\begin{tabular}{cc}
\hline Keterangan & Pretest \\
\hline Lo $_{0}$ & 0,1514 \\
Ltabel & 0,200 \\
Kriteria & Berdistribusi Normal \\
\hline
\end{tabular}

Berdasarkan Tabel 2 dari hasil uji normalitas data awal (pretest) dapat dilihat bahwa terdapat $\mathrm{L}_{0}=$ 0,1514 dengan taraf signifikan 0,05 dengan jumlah sampel delapan belas sehingga didapatkan Ltabel = 0,200 . Jadi $\mathrm{L}_{0}<$ Ltabel yaitu $0,1514<0,200$ maka artinya data berdistribusi normal. Jadi data nilai pretest menunjukkan bahwa sampel berasal dari populasi berdistribusi normal.

Berdasarkan hasil perhitungan dengan menggunakan microsoft excel pada uji normalitas awal dan uji normalitas akhir, bahwa hasil nilai pretest dan posttest siswa mengenai minat belajar siswa dalam maata pelajaran Ilmu Pengetahuan Alam berasal dari data yang berdistribusi normal. Kemudian untuk langkah yang terakhid untuk dilakukan adalah pengujian hipotesis yaitu menggunakan uji t. Pengujian hipotesis ini dilakukan untuk mengetahui adanya perbedaan minat belajar siswa antara sebelum diberi perlakuan dan setelah diberi perlakuan menggunakan Teams Games Tournament yang dapat dilihat dari hasil nilai pretest dan posttest siswa. Penelitian ini bertujuan untuk mengetahui seberapa besar keefektifan, maka terlebih dahulu merumuskan hipotesis nihil (H0) dan hipotesis alternative (Ha).

Tabel 3. Hasil Uji Normalitas Data Akhir

\begin{tabular}{ll}
\hline Keterangan & Pretest \\
\hline $\mathbf{L}_{\mathbf{0}}$ & 0,1022 \\
$\mathbf{L}_{\text {tabel }}$ & 0,200 \\
Kriteria & Berdistribusi Normal \\
\hline
\end{tabular}

Berdasarkan Tabel 3 dari hasil posttest dapat dilihat bahwa terdapat $\mathrm{L}_{0}=0,1022$ dengan taraf signifikan 0,05 dengan jumlah sampel 18 sehingga didapatkan $\mathrm{L}_{\text {tabel }}=0,200$ Jadi $\mathrm{L}_{0}<\mathrm{L}_{\text {tabel }}$ yaitu $0,1514<$ 0,200 maka artinya data berdistribusi normal. Jadi data nilai posttets menunjukkan bahwa sampel berasal dari populasi berdistribusi normal. Data hasil uji normalitas tersebut selanjutnya dilkukan pengujian hipotesis menggunakan uji $\mathrm{t}$ untuk mengetahui efektif tidaknya model pembelajaran Teams Games Tournament terhadap minat belajar siswa dengan rumus sebagai berikut:

$$
=\frac{M d}{\sqrt{\frac{5 x^{2}-d}{(N d N-1)}}}
$$

Keterangan:

$\mathrm{Md} \quad=$ mean dari angket minat belajar sebelum dan sesudah perlakuan.

$\mathrm{Xd} \quad=$ deviasi masing-masing subyek $(\mathrm{d}-\mathrm{Md})$

$\Sigma \mathrm{x}^{2} \quad=$ jumlah kuadrat deviasi

$\mathrm{N} \quad$ = subyek pada sampel

Uji hipotesis ini (uji t) digunakan untuk mengetahui perbedaan hasil angket minat belajar siswa sebelum diberi perlakuan dan setelah diberi perlakuan menggunakan model pembelajran Teams Games Tournament. Dengan memiliki hipotesis sebagai berikut:

$\mathrm{H}_{0}$ : Jika $t_{\text {hitung }} \leq \mathrm{t}_{\text {tabel }}$ maka $\mathrm{H}_{0}$ diterima atau dapat dikatakan bahwa model Teams Games Tournament tidak efektif terhadap minat belajar siswa kelas V SDN 01 Ngeling Kabupaten Jepara.

Ha: Jika $t_{\text {hitung }} \leq t_{\text {tabel }}$ maka $\mathrm{H}_{\mathrm{a}}$ diterima atau dapat dikatakan bahwa model Teams Games Tournament efektif terhadap minat belajar siswa kelas V SDN 01 Ngeling Kabupaten Jepara. 
Tabel 4. Hasil perhitungan Uji T

\begin{tabular}{llll}
\hline Uji t & Pretest & Nilai & Posttest \\
\hline Jumlah & 1365 & & 1570 \\
Rata-rata & 75,83 & 11,39 & 87,22 \\
$\mathbf{M d}$ & & 205 & \\
$\mathbf{\Sigma d}$ & & 458,28 & \\
$\mathbf{\Sigma} \mathbf{X}^{2} \mathbf{d}$ & & 18 & \\
$\mathbf{N}$ & & 306 & \\
$\mathbf{N}(\mathbf{N}-\mathbf{1})$ & & 9,307 & \\
$\mathbf{t}_{\text {hitung }}$ & & 2,110 & \\
ttabel & & Hoditolak & \\
Keterangan & & \\
\end{tabular}

Berdasarkan dari Tabel 4 dapat dilihat bahwa dari hasil perhitungan diketahui bahwa rata-rata posttest didapatkan sebesar 87,22 dan rata-rata pretets sebesar 75,83 , maka dapat dilihat bahwa rata-rata posttets lebih tinggi dari rata-rata pretest.

Selanjutnya juga diperoleh thitung sebesar 9,307, selanjutnya dengan taraf signifikansi sebesar $5 \%$ maka diperoleh tabel sebesar 2,110, sehingga diperoleh thitung $>t_{\text {tabel }}$ yaitu 9,307 $>2,110$, maka artinya $\mathrm{H}_{0}$ ditolak dan $\mathrm{H}_{\mathrm{a}}$ diterima. Dengan demikian dapat disimpulkan bahwa model Teams Games Tournament efektif terhadap minat belajar IPA siswa kelas V SDN 01 Ngeling Kabupaten Jepara.

\section{Simpulan dan Saran}

Berdasarkan hasil penelitian yang telah dilakukan dapat disimpulkan bahwa model Teams Games Tournament terbukti efektif terhadap minat belajar IPA siswa kelas V SDN 01 Ngeling Kaupaten Jepara. Hal ini berdasarkan hasil penelitian menggunakan uji-t diperoleh thitung $>$ ttabel yaitu 9,305 > 2,110, maka HO ditolak dan Ha diterima artinya rata-rata skor angket minat belajar IPA siswa sebelum diberi perlakuan lebih kecil dari rata-rata setelah diberi perlakuan. Adapun saran yang dapat disampaikan melalui penelitian ini adalah 1) kepada guru, dalam melaksanakan proses pembelajaran, guru dapat menggunakan model TGT pada penelitian ini sebagai referensi dalam mengajarkan IPA (2) kepada kepala sekolah, hendaknya kepala sekolah memfasilitasi guru dalam mengembangkan minat belajar siswa melalui model pembelajaran yang inovatif, agar tercipta pembelajaran yang menyenangkan dan bermakna; (3) kepada peneliti lain yang ingin melakukan penelitian model pembelajaran dapat menjadikan penelitian ini sebagai referensi terkait penelitian sejenis.

\section{Daftar Rujukan}

Daryanto. (2010). Belajar dan Mengajar. Bandung: Yrama Widya.

Dimyati \& Mudjiono. (2009). Belajar dan Pembelajaran. Jakarta: Rineka Cipta.

Fathurrohman, M. (2017). Model-model Pembelajaran Inovatif. Jogjakarta: AR-RUZZ MEDIA.

Kariyana, I. K. (2014). Implementasi Pembelajaran Kooperatif TGT untuk Meningkatkan Aktivitas dan Hasil Belajar Dribbling Sepakbola. Jurnal Penjakora, 2(1), 1-11.

Nurhasanah \& Soebandi. (2016). Minat Belajar Sebagai Determinasi Hasil Belajar Siswa.

Pratiwi, A. (2012). Pengaruh Permainan danMotivasi Anak Terhadap PenguasaanKonsep Matematika Anak Usia Dini. Jurnal Pendidikanan, 18(2), 106-121.

Purwandari, A. \& D. T. W. (2017). Eksperimen Model Pembelajaran Teams Games Tournament (TGT) Berbantuan Media Keranjang Biji-Bijian terhadap Hasil Belajar Materi Perkalian dan Pembagian Siswa Kelas II SDN Saptorenggo. Jurnal Ilmiah Sekolah Dasar, 1(3), 163-170. 
Riwahyudin, A. (2015). Pengaruh Sikap Siswa dan Minat Belajar Siswa Terhadap Hasil Belajar IPA Siswa Kelas V Sekolah Dasar Di Kabupaten Lamandau. Jurnal Pendidikan Dasar.

Sardiman, A. M. (2012). Interaksi \& Motivasi Belajar Mengajar. Jakarta: PT RajaGrafindo.

Slameto. (2010). Belajar Dan Faktor yang Mempengaruhinya. Jakarta: Bumi Aksara.

Slavin, R. E. (2009). Cooperative Learning: Teori, Riset dan Praktik. Bandung: Nusamedia.

Sohimin, A. (2014). 68 Model Pembelajaran Inovatif dalam Kurikulum 2013. Yogyakarta: AR-RUZZ MEDIA.

Sudimahayasa, N. (2015). Penerapan Model Pembelajaran TGT Untuk Meningkatkan Hasil Belajar, Partisipasi, dan Sikap Siswa. Jurnal Pendidikan Dan Pengajaran, 1(3), 45-53.

Susanna. (2017). Penerapan Teams Games Tournament (TGT) Melalui Media Kartu Domino Pada Materi Minyak Bumisiswa Kelas XI MAN 4 Aceh Besar. Lantanida Journal, 5(2), 93-196. Retrieved from https://www.researchgate.net/publication/334369634_PENERAPAN_TEAMS_GAMES_TOURNAME NT_TGT_MELALUI_MEDIA_KARTU_DOMINO_PADA_MATERI_MINYAK_BUMI_SISWA_KELAS_XI_MAN _4_ACEH_BESAR/fulltext/5d25f88e299bf1547ca94690/PENERAPAN-TEAMS-GAMESTOURNAMENT-TGT-MELALUI-MEDIA

Susanto, A. (2010). Teori Belajar \& Pembelajaran di Sekolah Dasar. Jakarta: Prenadamedia Group.

Taniredja, Tukiran \& Faridli, Efi Miftah \& Harmianto, S. (2011). Model-model pembelajaran inovatif. Bandung: Alfabeta.

Trianto. (2014). Model Pembelajaran Terpadu. Jakarta: Bumi Aksara.

Undang-undang Nomor 20 tahun 2003 tentang Sistem Pendidikan Nasional. 